\title{
The Influence of Discipline and Motivation on Employee Performance in PT. Panca Usaha Lestari in Jakarta
}

\author{
Mohamad Duddy Dinantara \\ Pamulang University, Indonesia \\ Email: dosen0081@unpam.ac.id
}

(Received: February 20-2020; revised: May20-2020; published: June 31-2020)

\begin{abstract}
The discipline of work that is not going well will have an impact on the progress of the organization. Without good discipline in employees, it is difficult for organizations to achieve optimal results. This study aims to determine the effect of discipline and motivation on employee performance at PT. Panca Usaha Sustainable in Jakarta. The method used was explanatory research with a sample of 62 respondents. The analysis technique uses statistical analysis with regression testing, correlation, determination, and hypothesis testing. The results of this study have a significant effect on discipline employee performance by $47.1 \%$, hypothesis testing obtained significance $0,000<0.05$. Motivation has a significant effect on employee performance by $38.7 \%$, hypothesis testing obtained significance 0,000 $<0.05$. Discipline and simultaneous significant effect on employee performance by $56.9 \%$, hypothesis testing obtained significance $0,000<0.05 .0$ ).
\end{abstract}

Keywords: Discipline, motivation, employee performance

\section{INTRODUCTION}

The Role of Human Resources in the company is very important, considering that employees as executors of the goals or objectives achieved by the company (Blaga \& Jozsef, 2014; Vardarlier, 2016). Therefore it is important that company management always provides direction and motivation and also ensures that all regulations in the company can be adhered to properly by all employees both at management level until employees are at a low level (Córdova et al., 2019; Cui et al., 2019; Sharafoddin \& Emsia, 2016).

The discipline of work that is not going well will have an impact on the progress of the organization (S. Doyle, 2019; Suprapto et al., 2018; Waris, 2015). Without good discipline in employees, it is difficult for organizations to achieve optimal results. Undisciplined (Indisciplinary) action will have an impact on the growth of the company's organization. Discipline is also said as a means to train and educate people on rules so that there is compliance and so that it can run in a thin and orderly manner in the organization. Company regulations are made of course aimed at being able to be obeyed by employees both from the obedience of employees in keeping work time, obedience in complying with all the rules in the company, compliance with employee behavior in carrying out their duties and obligations, employee obedience in upholding legal norms and other rules.

Enforcing discipline is important for the company because discipline contains rules that employees must obey (Saleh, 2014; Sarman et al., 2015). Discipline is expected to make work as efficient as possible. Work discipline can be seen as something of great benefit, both for the benefit of the organization and for employees. For organizations, the existence of work discipline will guarantee the maintenance of order and the smooth implementation of tasks, so 
244|Jurnal Ilmiah Ilmu Administrasi Publik: Jurnal Pemikiran dan Penelitian Administrasi Publik

Volume io Number 1, January - June 2020. Page 243-252

that optimal results are obtained (Levine \& Modica, 2016; Waris, 2015). Whereas employees will get a pleasant working atmosphere so that they will increase their work spirit in carrying out their work. Employees must also have a high sense of responsibility to show our discipline in work, such as doing given tasks and completing them on time. Disciplined workers not only always accept the given task, but completing the task perfectly is also a form of responsibility for the job.

Motivation will arise if humans already feel fulfilled all their needs (Alfian et al., 2019; Graham, 2020; Kanat-Maymon et al., 2020; Taguchi, 2015), Therefore, if the needs are not met, it will cause problems. which led to several cases that often occur in the company such as labor strikes, demands for wage increases and so on, this is a sign that there is a dissatisfaction felt by employees of the company. The role of motivation is to intensify these desires and desires, therefore it can be concluded that efforts to increase one's morale will always be related to motivating efforts so that to carry out good motivation needs to know human needs (Nasrullah et al., 2017; Niswaty et al., 2017; Salam et al., 2018; Sunarsi, 2018a, 2018b, 2018c).

According to (Maslow, 1943)), that motivation is a driving force that creates the excitement of one's work so that they want to work together, work effectively, and be integrated with all their efforts to achieve satisfaction at work. In its role as the main element of a company that refers to policies and procedures, understanding and developing HR in an organization is very important (Chen \& Klimoski, 2007; Kazakovs et al., 2015; Zhang \& Nesbit, 2018). Important factors that influence employee performance are work motivation, work discipline, and job satisfaction so that goals can be achieved.

The influence of motivation from superiors and companies is very important to improve employee welfare and discipline that grows from oneself is very important so that a sense of responsibility arises at work. With the influence of motivation, work discipline and job satisfaction will make employees more advanced.

Performance can be achieved by companies by building all elements within the company to be able to work effectively. According to (Mangkunegara, 2011)) the notion of performance is the quality and quantity of work achieved by an employee in carrying out his duties following the responsibilities given to him.

\section{METHOD}

The type of research used is associative, where the aim is to find out the search for interconnection. The population in this study amounted to 62 employees of PT. Panca Usaha Lestari in Jakarta. The sampling technique in this study is saturated sampling, where all members of the population are sampled. Thus the sample in this study amounted to 62 respondents. In analyzing the data used the instrument test, classical assumption test, regression, coefficient of determination, and hypothesis testing.

\section{RESULT AND DISCUSSION}

This test used to determine the highest minimum and maximum scores, ratting scores, and standard deviations of each variable. 
Table 1.

Results of Descriptive Statistics Analysis

Descriptive Statistics

\begin{tabular}{llrrrr}
\hline & N & Minimum & Maximum & Mean & \multicolumn{1}{c}{ Std. Deviation } \\
\hline Work Discipline (X1) & 62 & 31 & 48 & 38.19 & 4.288 \\
Motivation (X2) & 62 & 31 & 48 & 38.26 & 3.887 \\
Employee Performance (Y) & 62 & 33 & 46 & 39.27 & 3.636 \\
Valid N (listwise) & 62 & & & & \\
\hline
\end{tabular}

Discipline obtained a minimum variance of 31 and a maximum variance of 48 with a rating score of 38.19 with a standard deviation of 4.288. Motivation obtained a minimum variance of 31 and a maximum variance of 48 with a rating score of 38.26 with a standard deviation of 3.887. Employee performance obtained a minimum variance of 33 and a maximum variance of 46 with a rating score of 39.27 with a standard deviation of 3,636.

\section{The Influence of Work Discipline on Employee Performance}

This analysis is intended to determine the effect of work discipline variables on employee performance. Before assessing the influence of variables, first, a correlation coefficient analysis is carried out which aims to determine the level of relationship strength of the work discipline variables. The results of testing the correlation coefficient of work discipline on employee performance.

The coefficient of determination analysis is intended to find out the percentage of the effect of the discipline variable on employee performance variables. The test results are as follows:

Table 2.

Discipline Determination Coefficient Testing Results on Employee Performance Model Summary

\begin{tabular}{lr|r|r|r}
\hline Model & R & R Square & Adjusted R Square & \multicolumn{2}{c}{$\begin{array}{c}\text { Std. Error of the } \\
\text { Estimate }\end{array}$} \\
\hline 1 & $.686^{\mathrm{a}}$ & .471 & .462 & 2.666 \\
\hline
\end{tabular}

a. Predictors: (Constant), Work Discipline (X1)

Based on the test results obtained a determination value of 0.471 means that discipline has an influence contribution of $47.1 \%$ on employee performance. 
246 Jurnal Ilmiah Ilmu Administrasi Publik: Jurnal Pemikiran dan Penelitian Administrasi Publik Volume 10 Number 1, January - June 2020. Page 243-252

Table 3.

Disciplinary Hypothesis Test Results on Employee Performance

Coefficients $^{\mathbf{a}}$

\begin{tabular}{|c|c|c|c|c|c|c|}
\hline \multirow[b]{2}{*}{ Model } & & \multicolumn{2}{|c|}{$\begin{array}{l}\text { Unstandardized } \\
\text { Coefficients }\end{array}$} & \multirow{2}{*}{$\begin{array}{c}\text { Standardized } \\
\text { Coefficients } \\
\text { Beta }\end{array}$} & \multirow{3}{*}{$\begin{array}{c}\mathrm{t} \\
5.573\end{array}$} & \multirow{3}{*}{$\begin{array}{l}\text { Sig. } \\
.000\end{array}$} \\
\hline & & $\mathrm{B}$ & Std. Error & & & \\
\hline \multirow[t]{2}{*}{1} & (Constant) & 17.049 & 3.059 & & & \\
\hline & Work Discipline (X1) & .582 & .080 & .686 & 7.310 & .000 \\
\hline
\end{tabular}

a. Dependent Variable: Employee Performance (Y)

Based on the test results in the above table, the value of $t$ count $>t$ table or $(7.310>2,000)$ is obtained, thus the first hypothesis proposed

\section{The Influence of Motivation on Employee Performance}

This analysis is intended to determine the effect of work motivation variables on employee performance. Before assessing the influence of variables, first, a correlation coefficient analysis is performed which aims to determine the level of strength of the relationship of work motivation variables on employee performance variables. The results of testing the correlation coefficient of work motivation on employee performance are as follows:

Table 4.

Motivation Correlation Coefficient Test Results on Employee Performance

Correlations $^{\mathbf{b}}$

\begin{tabular}{|c|c|c|c|}
\hline & & $\begin{array}{l}\text { Motivation } \\
\text { (X2) }\end{array}$ & $\begin{array}{c}\text { Employee } \\
\text { Performance (Y) }\end{array}$ \\
\hline Motivation (X2) & $\begin{array}{l}\text { Pearson Correlation } \\
\text { Sig. (2-tailed) }\end{array}$ & 1 & $\begin{array}{r}.622^{* *} \\
.000\end{array}$ \\
\hline Employee Performance (Y) & $\begin{array}{l}\text { Pearson Correlation } \\
\text { Sig. (2-tailed) }\end{array}$ & $\begin{array}{r}.622^{* *} \\
.000\end{array}$ & 1 \\
\hline
\end{tabular}

b. Listwise $\mathrm{N}=62$

Based on the test results obtained a correlation value of 0.622 means that motivation has a strong relationship to employee performance.

Table 5.

Motivation Determination Test Results for Employee Performance

Model Summary

\begin{tabular}{lrr|r|r|r}
\hline Model & & & & \multicolumn{2}{c}{$\begin{array}{c}\text { Std. Error of the } \\
\text { Estimate }\end{array}$} \\
\hline 1 & $\mathrm{R}$ & \multicolumn{2}{c|}{ R Square } & Adjusted R Square & 2.869 \\
\hline
\end{tabular}

a. Predictors: (Constant), Motivation (X2) 
Based on the test results obtained a determination value of 0.387 means that motivation has a contribution of $38.7 \%$ influence on employee performance.

Table 6.

Motivation Hypothesis Test Results on Employee Performance

Coefficients $^{\mathbf{a}}$

\begin{tabular}{|c|c|c|c|c|c|c|}
\hline \multirow{2}{*}{\multicolumn{2}{|c|}{ Model }} & \multicolumn{2}{|c|}{$\begin{array}{c}\text { Unstandardized } \\
\text { Coefficients }\end{array}$} & \multirow{2}{*}{$\begin{array}{c}\text { Standardized } \\
\text { Coefficients } \\
\text { Beta }\end{array}$} & \multirow[b]{2}{*}{6} & \multirow[b]{2}{*}{ Sig. } \\
\hline & & B & Std. Error & & & \\
\hline 1 & (Constant) & 17.005 & 3.634 & & 4.680 & .000 \\
\hline & Motivation (X2) & .582 & .095 & .622 & 6.160 & .000 \\
\hline
\end{tabular}

a. Dependent Variable: Employee performance (Y)

Based on the test results in the above table, the value of $t$ count $>t$ table or $(6.160>2,000)$ is obtained, thus the second hypothesis proposed that there is a significant influence between motivation on employee performance is accepted.

\section{The Influence of Work Discipline and Work Motivation on Employee Performance}

This analysis is intended to determine the effect of work discipline variables and work motivation on employee performance. Before assessing the influence of variables, first, a correlation coefficient analysis is performed which aims to determine the level of relationship strength of the work discipline variables and work motivation on employee performance variables. The results of testing the correlation coefficient of work discipline and work motivation on employee performance are as follows:

Table 7.

Test Results for Work Discipline Correlation Coefficient and Motivation on Employee Performance

Model Summary

\begin{tabular}{|c|c|c|c|c|}
\hline Model & $\mathrm{R}$ & R Square & Adjusted R Square & $\begin{array}{l}\text { Std. Error of the } \\
\text { Estimate }\end{array}$ \\
\hline 1 & $.754^{\mathrm{a}}$ & .569 & .554 & 2.42 \\
\hline
\end{tabular}

a. Predictors: (Constant), Motivation (X2), Work Discipline (X1)

Based on the test results obtained by the correlation value of 0.754 means that discipline and motivation simultaneously have a strong relationship to employee performance. 
248 Jurnal Ilmiah Ilmu Administrasi Publik: Jurnal Pemikiran dan Penelitian Administrasi Publik Volume 10 Number 1, January - June 2020. Page 243-252

Table 8.

Multiple Regression Testing Results

\begin{tabular}{|c|c|c|c|c|c|}
\hline & \multicolumn{3}{|c|}{ Coefficients $^{a}$} & \multirow[b]{3}{*}{$\mathrm{t}$} & \multirow[b]{3}{*}{ Sig. } \\
\hline \multirow[b]{2}{*}{ Model } & \multicolumn{2}{|c|}{$\begin{array}{l}\text { Unstandardized } \\
\text { Coefficients }\end{array}$} & $\begin{array}{c}\text { Standardized } \\
\text { Coefficients }\end{array}$ & & \\
\hline & B & Std. Error & Beta & & \\
\hline (Constant) & 10.081 & 3.373 & & 2.989 & .004 \\
\hline Work Discipline (X1) & .422 & .085 & .498 & 4.987 & .000 \\
\hline Motivation (X2) & .342 & .093 & .366 & 3.663 & .001 \\
\hline
\end{tabular}

a. Dependent Variable: Employee performance (Y)

Based on the test results in the above table, the regression equation $\mathrm{Y}=10.081+$ $0.422 \mathrm{X} 1+0.342 \mathrm{X} 2$ is obtained. From the equation, it is explained that a constant of 10,081 means that if there is no discipline and motivation, then there is an employee performance value of 10,081 points. The discipline regression coefficient of 0.422 , this number is positive meaning that every time there is an increase in work discipline by 0.422 , the employee's performance will also increase by 0.422 points. The regression coefficient of motivation is 0.342 , this number is positive meaning that every time there is an increase in motivation by 0.342 , the employee's performance will also increase by 0.342 points.

Hypothesis testing with the F test is used to find out which simultaneous hypotheses are accepted. The third hypothesis: there is a significant effect between discipline and motivation on employee performance.

Table 9.

Disciplinary Hypothesis Test Results and Motivation Against Employee Performance ANOVA $^{\mathrm{a}}$

\begin{tabular}{llr|r|r|r|r}
\hline Model & Sum of Squares & \multicolumn{1}{c|}{ df } & Mean Square & \multicolumn{1}{c|}{ F } & \multicolumn{1}{c}{ Sig. } \\
\hline 1 & Regression & 458.839 & 2 & 229.420 & 38.952 & $.000^{\mathrm{b}}$ \\
\cline { 2 - 7 } & Residual & 347.499 & 59 & 5.890 & & \\
\cline { 2 - 7 } & Total & 806.339 & 61 & & & \\
\hline
\end{tabular}

a. Dependent Variable: Employee performance (Y)

b. Predictors: (Constant), Motivation (X2), Work Discipline (X1)

Based on the test results in the above table, obtained count> F table or $(38.952>2.760)$, thus the third hypothesis proposed that there is a significant influence between discipline and motivation on employee performance is accepted.

\section{Discussion}

\section{The Influence of Discipline on Employee Performance}

Discipline has a significant effect on employee performance with a correlation of 0.686 or has a strong relationship with an influential contribution of $47.1 \%$. Hypothesis testing obtained $t$ 
count $>\mathrm{t}$ table or $(7.310>2,000)$. Thus the first hypothesis proposed that there is a significant effect between discipline on employee performance is accepted.

\section{The Influence of Motivation on Employee Performance}

Motivation has a significant effect on employee performance with a correlation of 0.622 or has a strong relationship with a contribution of $38.7 \%$. Hypothesis testing obtained $t$ count $>t$ table or $(6.160>2,000)$. Thus the second hypothesis proposed that there is a significant effect between motivation on employee performance is accepted.

\section{The Influence of Discipline and Motivation on Performance}

Discipline and motivation have a significant effect on employee performance by obtaining a regression equation $\mathrm{Y}=10,081+0.422 \mathrm{X} 1+0.342 \mathrm{X} 2$, the correlation value of 0.754 , or has a strong relationship with the contribution of influence of $56.9 \%$ while the remaining $43.1 \%$ is influenced by other factors. Hypothesis testing obtained $\mathrm{F}$ count $>\mathrm{F}$ table or (38.952> 2.760). Thus the third hypothesis proposed that there is a significant effect between discipline and motivation on employee performance is accepted.

\section{CONCLUSION}

Discipline has a significant effect on employee performance with an influence contribution of $47.1 \%$. Hypothesis testing obtained $t$ count $>t$ table or $(7.310>2,000)$. Motivation has a significant effect on employee performance with an influence contribution of $38.7 \%$. Hypothesis testing obtained $t$ count $>t$ table or $(6.160>2,000)$. Discipline and motivation have a significant effect on employee performance with an influence contribution of $56.9 \%$ while the remaining $43.1 \%$ is influenced by other factors. Hypothesis testing obtained $\mathrm{F}$ count $>\mathrm{F}$ table or $(38.952>2.760)$.

\section{REFERENCES}

Alfian, M., Niswaty, R., Darwis, M., Arhas, S. H., \& Salam, R. (2019). Motivasi Kerja Pegawai pada Sekretariat Dewan Perwakilan Rakyat Daerah Kabupaten Gowa. 1, 35-44.

Blaga, P., \& Jozsef, B. (2014). Human Resources, Quality Circles and Innovation. Procedia Economics and Finance, 15, 1458-1462. https://doi.org/https://doi.org/10.1016/S22125671(14)00611-X

Chen, G., \& Klimoski, R. J. (2007). Training and development of human resources at work: Is the state of our science strong? Human Resource Management Review, 17(2), 180-190. https://doi.org/https://doi.org/10.1016/j.hrmr.2007.03.004

Córdova, F. M., Durán, C. A., Pincheira, M., Palominos, F., \& Galindo, R. (2019). Knowledge Management of Intangible Actives in Service Companies. Procedia Computer Science, 162, 596-603. https://doi.org/https://doi.org/10.1016/j.procs.2019.12.028

Cui, Y., Zhang, Y., Guo, J., Hu, H., \& Meng, H. (2019). Top management team knowledge 
250 Jurnal Ilmiah Ilmu Administrasi Publik: Jurnal Pemikiran dan Penelitian Administrasi Publik Volume 10 Number 1, January - June 2020. Page 243-252

heterogeneity, ownership structure and financial performance: Evidence from Chinese IT listed companies. Technological Forecasting and Social Change, 140, 14-21. https://doi.org/https://doi.org/10.1016/j.techfore.2018.12.008

Doyle, S. (2019). Section 6 - Discipline-Specific Quality Management (S. B. T.-Q. M. in F. S. Doyle (ed.); pp. 245-323). Academic Press. https://doi.org/https://doi.org/10.1016/B9780-12-805416-1.00006-2

Graham, S. (2020). An attributional theory of motivation. Contemporary Educational Psychology, 101861. https://doi.org/https://doi.org/10.1016/j.cedpsych.2020.101861

Kanat-Maymon, Y., Elimelech, M., \& Roth, G. (2020). Work motivations as antecedents and outcomes of leadership: Integrating self-determination theory and the full range leadership theory. European Management Journal. https://doi.org/https://doi.org/10.1016/j.emj.2020.01.003

Kazakovs, M., Verdina, A., \& Arhipova, I. (2015). Automation of Human Resources Development Planning. Procedia Computer Science, 77, 234-239. https://doi.org/https://doi.org/10.1016/j.procs.2015.12.379

Levine, D. K., \& Modica, S. (2016). Peer Discipline and Incentives within Groups. Journal of Economic Behavior \& Organization, 123, 19-30. https://doi.org/https://doi.org/10.1016/j.jebo.2015.12.006

Mangkunegara. (2011). Manajemen Sumber Daya Perusahaan. In Manajemen Sumber Daya Perusahaan.

Maslow, A. H. (1943). A theory of human motivation. Psychological Review. https://doi.org/10.1037/h0054346

Nasrullah, M., Salam, R., Pratiwi, D., \& Niswaty, R. (2017). Motivasi Kerja Pegawai Di Kantor Keyahbandaran Utama Makassar. Jurnal Ilmiah Manajemen Dan Bisnis, 18(2), 206-211.

Niswaty, R., Rusbiati, S., Jamaluddin, J., \& Salam, R. (2017). The Influence of Teacher's Reinforcement for Students Motivation. International Conference on Education, Science, Art and Technology, 148-152.

Salam, R., Akib, H., \& Daraba, D. (2018). Utilization of Learning Media In Motivating Student Learning. 1st International Conference on Social Sciences (ICSS 2018).

Saleh, S. (2014). PENEGAKAN DISIPLIN (Suatu Upaya Peningkatan Kinerja Pegawai). Jurnal Ad'ministrare, 1(1), 8-19.

Sarman, H., Akib, H., \& Niswaty, R. (2015). Pengaruh Pengawasan Terhadap Disiplin Kerja Pegawai Pada Kantor Kecamatan Ujung Kota Parepare. Jurnal Office, 1(2), 115-122.

Sharafoddin, S., \& Emsia, E. (2016). The Effect of Stock Valuation on the Company's Management. Procedia Economics and Finance, 36, 128-136. https://doi.org/https://doi.org/10.1016/S2212-5671(16)30024-7

Sunarsi, D. (2018a). Analisis Motivasi Kerja Tenaga Pendidik Sukarela Pada Pusat Kegiatan Belajar Masyarakat (PKBM) Bimasda Kota Tangerang Selatan. Kreatif: Jurnal Ilmiah Prodi Manajemen Universitas Pamulang, 6(2), 53-65.

Sunarsi, D. (2018b). Pengaruh Gaya Kepemimpinan, Motivasi Dan Disiplin Kerja Terhadap 
Kinerja Pendidik Yayasan Marvin. Inovasi, 5(1), 1-18.

Sunarsi, D. (2018c). Pengaruh Motivasi Dan Disiplin Terhadap Produktivitas Kerja Karyawan Pada PT. Nadi Suwarna Bumi. Jurnal Semarak, 1(1).

Suprapto, S., Pomalingo, N., \& Akib, H. (2018). The implementation of a culture of discipline for the state civil apparatus (ASN) in Gorontalo Regency (A Study of the Application of Discipline Ambassador Vest). 1st International Conference on Social Sciences (ICSS 2018).

Taguchi, Y. (2015). Factors Forming Work Motivation in Japan. Procedia Manufacturing, 3, 717-722. https://doi.org/https://doi.org/10.1016/j.promfg.2015.07.314

Vardarlier, P. (2016). Strategic Approach to Human Resources Management During Crisis. Procedia - Social and Behavioral Sciences, 235, 463-472. https://doi.org/https://doi.org/10.1016/j.sbspro.2016.11.057

Waris, A. P. M. dan A. (2015). Effect of Training, Competence and Discipline on Employee Performance in Company (Case Study in PT. Asuransi Bangun Askrida). Procedia Social and Behavioral Sciences. https://doi.org/10.1016/j.sbspro.2015.11.165

Zhang, Y. E., \& Nesbit, P. L. (2018). Talent Development in China: Human resource managers' perception of the Value of the MBA. The International Journal of Management Education, 16(3), 380-393. https://doi.org/https://doi.org/10.1016/j.ijme.2018.06.001 
252 Jurnal Ilmiah Ilmu Administrasi Publik: Jurnal Pemikiran dan Penelitian Administrasi Publik Volume io Number 1, January - June 2020. Page 243-252 